\title{
Trechnology
}

\section{Greenhouse Cost Accounting: A Computer Program for Making Management Decisions}

\author{
Robin G. Brumfield
}

Additional index words. floriculture, planning, microcomputer, decision-making, enterprise budget, cost analysis, extension, education

Summary. The computer program Greenhouse Cost Accounting, available for DOS-based microcomputers and Macintosh computers, is described. The software enables the user to perform cost accounting and to determine the profitability of greenhouse crops. The information can be used by managers to analyze various production, financial, and marketing strategies. The Greenhouse Cost Accounting program uses cost information typically found on income statements and direct cost information for each crop. From these inputs, the program allocates as many costs as possible to individual crops. The remaining unallocated costs are assigned to each crop on a per square-foot-week basis. The computer output provides information on costs and returns on a per crop, per unit, and per square-foot basis. It also provides an income statement showing total costs, allocated costs, and unallocated costs. The output can aid the manager in making decisions about pricing, reducing unprofitable production, controlling costs, and increasing sales of profitable crops. The program also can be used by greenhouse management classes or for extension workshops.

$\mathrm{P}$ rofit for any business can be calculated by the simple formula: profit $=$ number of units sold $\times$ (sales price per unit - total costs per unit). Greenhouse owners know how many units of a specific crop they sell at a given price. They also know the profitability of their business from

Department of Agricultural Economics and Marketing, P.O. Box 231, Rutgers University, New Brunswick, NJ 08903-0231.

New Jersey Agricultural Experiment Station Publication no. D-02222-1-91. their income tax records at the end of the year. However, most growers produce many crops in many different sizes. The third vital component of the profit equation, the cost of producing an individual unit, is often not known. However, determining the profitability for a crop requires knowledge of its production costs. The process of assigning production costs to each crop and subsequently calculating the profit of each crop is called cost accounting.

Universities have developed computer programs for costing landscape jobs (Smith and Arminio, 1986) and for making managerial decisions for other horticultural crops (Crassweller et al., 1989; Creasy, 1986; Embree et al., 1991; Hall et al., 1989). Programs to predict production costs for greenhouse and nursery crops also have been written (Power et al., 1991; Rhodus et al., 1987; Tripepi and Kuchar, 1988). Commercial accounting software tailored to greenhouses, such as Micro Vane Plant (distributed by Mico Vane, 813 Cox Dr., Kalamazoo, MI 49002), also has been developed.

I describe here the computer program Greenhouse Cost Accounting, distributed by Rutgers Univ. Cooperative Extension, which can be used on microcomputers with a DOS operating system. This program is also available for Macintosh computers from The Pennsylvania State Univ., University Park, PA 16802.

\section{Objectives}

The program was designed to meet the following objectives:

1) Allow greenhouse managers to allocate as many variable costs as possible from the income statement to specific crops. The program will then total the overhead costs and variable costs that cannot be allocated directly to specific crops and will allocate them to each crop on a per square-foot-week basis.

2) Allow managers to determine the profit or loss of each crop.

3) Provide a tool for use in financial and production management.

4) Provide managers with information to reduce costs.

5) Provide a planning tool to identify and eliminate unprofitable crops and increase profitable ones.

6) Provide necessary cost data for pricing plants.

Managers can use the software to analyze various strategies to improve the overall profitability of their businesses. This can be done by entering either hypothetical crops into the program or hypothetical changes in the current production system and comparing the results to that system. This program also could be used for student instruction in floricultural production and management or in workshops and other programs that teach greenhouse management.

The Greenhouse Cost Accounting program begins by collecting information typically contained in income statements that are readily available to managers. The user then enters information on direct costs of each crop. From this input, the program allocates as many costs as possible to individual crops. The program assigns the remaining unallocated costs from the income statement to each crop on a per square-foot-week basis. The program then calculates information on costs and returns per crop, per unit (pot 
or flat), and per square foot for each crop, as well as an income statement showing total costs, allocated costs, and unallocated costs.

\section{Data collection sheets}

Before using the computer program, managers can collect information from business records on blank data collection forms printed from the main menu. These data input collection forms are especially useful for county agents and others who can distribute them to managers. The county agent can run the software and print results for the manager.

Ifinformation for a particular item is unavailable, enter a zero. The program allocates unassigned costs on a per square-foot-week basis. All cells in the worksheet that should not be altered have been protected.

After entering all of the data, the user may view the worksheet. This option calculates the results and allows the user to verify that the data are correct before printing. The print option allows the user to print out the input information, the results, or blank collections sheets.

\section{Greenhouse Cost Accounting program}

The costs incurred in a greenhouse business can be grouped into two categories: variable and overhead costs. Variable costs are costs that change with the level of production and can usually be allocated to a particular crop. Examples ofvariable costs are the costs ofpetunia seeds and bedding plant flats; both relate specifically to petunia production. They are part of the total costs per unit given in the profitability equation above. Overhead or fixed costs are those costs that are incurred regardless of the level of production and are common to all crops. These costs include depreciation of the greenhouse structure, equipment, and other facilities and costs such as interest, repairs, insurance, taxes, and salaries of overhead personnel (i.e., the manager, sales people, growers, secretaries, bookkeepers, etc.). The total cost ofproduction is the sum ofvariable and overhead costs.

A business owner or manager may not know the various costs of producing a specific crop. For example, the total cost of seeds is usually known. However, the cost of petunia seeds may be unknown. If the cost ofpetunia seeds is known, enter it as a variable cost for producing petunias; if it is not known, enter a zero. The program will then assign the cost of seeds along with other unassigned costs on a per squarefoot-week basis.

\section{Cost accounting of a hypothetical business}

Input section. The program has two sections: the input section and results section. The input section is divided into two parts. The first part includes values from the income statement and space usage information. Table 1 is an example of input from the income statement for a 20,000$\mathrm{ft}^{2}$ greenhouse. If the detail requested by the program is unavailable, combine categories. For example, ifsalaries and wages are not kept separately, enter them under overhead salaries and enter $\$ 0$ under general wages.

The second part involves information on the cost of producing each crop (Table 2). The user supplies the name of each crop produced; the costs of labor, seeds or plants, containers, growing medium, fertilizer, chemicals, and tags; and other direct costs associated with the crop. For example, the cost of labor of producing petunia flats is $\$ 3385$. However, most managers probably do not know the cost of labor devoted to each crop. If the labor cost of producing petunia flats is unknown, enter $\$ 0$, and the program will assign labor costs on a per square-foot-week basis.

The user also enters the number of units started, the space devoted to each unit, the weeks needed to grow the crop, the percent sold, and the price per unit-items that most managers know for each crop. If the same crop is sold at more than one price, then that crop may be treated as two or more crops. For example, perhaps $20 \%$ ofpetunia flats are sold at \$6.00/flat to customers who buy more than 100 flats, and $80 \%$ were sold at $\$ 6.50$ to customers who buy less than 100 flats. Two entries can be made showing 4000 units started of "petunia flats-1" selling for $\$ 6.50$ and 1000 units started of "petunia flats-2" at $\$ 6.00$. Total costs can be allocated by the user on an $80 \% / 20 \%$ basis. Another option is to enter the average price for petunias.

Results section. The results section has three subsections: overhead costs, costs per crop, and costs per unit (flat or pot). The overhead cost subsection displays an income statement showing values that were entered under the income statement option, the values calculated from data for specific crops, and the unallocated costs (Table 3). The cost per unit subsection displays the following costs per unit for each crop: labor, seeds or plants, container, root media, fertilizer, chemicals, tags, other direct costs, total direct costs, overhead costs, loss of unsold plants, total costs, sales price, and profit or loss (Table 4). The cost per crop subsection displays the following costs for each crop: sum of direct costs, square feet per crop, square foot-weeks per crop, overhead costs per square foot-week, total crop sales, total crop costs, profit per crop, profit per unit, and profit per square foot-week. Totals for the entire business also are calculated for each of the above categories.

In the example, poinsettias are unprofitable, and the other crops are profitable (Table 4). Marigold flats are the most profitable crop per unit, and petunia flats are the second most profitable. In the cost per crop section of Table 4 , the overhead cost per square foot-week is $\$ 0.267$.

Differences in profit pictures exist between cost per square foot-week and cost per unit. Marigold flats are the most profitable crop per unit, but geraniums in 4-inch pots are the most profitable crop per square foot-week. Geraniums in 4-inch pots have a lower profit per pot, because they are sold at a lower price per unit than the marigold flats. However, geraniums in 4-inch pots are the most profitable crop per square foot-week because of more efficient use of space. Returns per square foot-week of bench space may be the most informative way of comparing profitability among crops because of differences in use of space.

The program provides the basic data for a greenhouse to meet the six objectives of the program stated previously:

1) Costs are allocated to specific crops, and the costs per unit for each crop are estimated.

2) The profit or loss of each crop is estimated. Four crops are profitable and one crop is unprofitable.

3) The program supplies the manager with information to use in financial and production management. Managers in this hypothetical example might find ways to increase sales of geraniums in 4-inch pots and marigolds in flats. They also might find ways to 
Table 1. An example of the first input screen, which includes income statement and space usage information, from the Greenhouse Cost Accounting program.

\begin{tabular}{|c|c|}
\hline \multicolumn{2}{|c|}{ Input section (1) } \\
\hline & $\begin{array}{l}\text { Values from } \\
\text { income statement }\end{array}$ \\
\hline Sales & $\$ 182,610$ \\
\hline \multicolumn{2}{|l|}{ Direct costs } \\
\hline Seeds, cuttings, or plants & $\$ 19,092$ \\
\hline Pots or containers & $\$ 9,490$ \\
\hline Growing medium & $\$ 9,150$ \\
\hline Fertilizer and chemicals & $\$ 1,130$ \\
\hline Tags & $\$ 3,788$ \\
\hline Other & $\$ 0$ \\
\hline Overhead salaries (including benefits) & $\$ 37,384$ \\
\hline General wages (including benefits) & $\$ 12,111$ \\
\hline \multicolumn{2}{|l|}{ Utilities } \\
\hline Heating fuel & $\$ 20,000$ \\
\hline Electricity & $\$ 3,350$ \\
\hline Telephone & $\$ 1,480$ \\
\hline Water & $\$ 0$ \\
\hline \multicolumn{2}{|l|}{ Overhead } \\
\hline Depreciation & $\$ 16,750$ \\
\hline Interest & $\$ 16,800$ \\
\hline Repairs & $\$ 3,725$ \\
\hline Taxes & $\$ 550$ \\
\hline Insurance & $\$ 3,240$ \\
\hline Advertising & $\$ 485$ \\
\hline Dues and subscriptions & $\$ 100$ \\
\hline Travel and entertainment & $\$ 345$ \\
\hline Office expense & $\$ 314$ \\
\hline Professional fees & $\$ 550$ \\
\hline Truck expense and equipment rental & $\$ 7,150$ \\
\hline Land rental & $\$ 2,000$ \\
\hline Contributions & $\$ 18$ \\
\hline Bad debts & $\$ 925$ \\
\hline Miscellaneous & $\$ 550$ \\
\hline Greenhouse area $\left(\mathrm{ft}^{2}\right)$ & 20,000 \\
\hline $\begin{array}{l}\text { Greenhouse space used for production (\%) } \\
\text { (e.g., enter } 75 \% \text { as } 75,125 \% \text { as } 125)\end{array}$ & 75 \\
\hline Weeks in operation (52 if a full year) & 29 \\
\hline
\end{tabular}

Table 2. An example of input section 2, which includes information on specific crops, from the Greenhouse Cost Accounting program.

\begin{tabular}{|c|c|c|c|c|c|c|}
\hline \multicolumn{7}{|c|}{ Input section (2) } \\
\hline & \multicolumn{6}{|c|}{ Crop } \\
\hline & $\begin{array}{l}\text { Petunia } \\
\text { flats }\end{array}$ & $\begin{array}{l}\text { Marigold } \\
\text { flats }\end{array}$ & $\begin{array}{l}\text { Geranium } \\
\text { flats }\end{array}$ & $\begin{array}{l}\text { Geranium } \\
\text { (4-inch pots) }\end{array}$ & $\begin{array}{l}\text { Poinsettias } \\
\text { (6-inch pots) }\end{array}$ & Total \\
\hline Labor & $\$ 3,385.00$ & $\$ 2,031.00$ & $\$ 3,385.00$ & $\$ 1,240.00$ & $\$ 2,070.00$ & $\$ 12,111.00$ \\
\hline Seeds or plants & $\$ 1,320.00$ & $\$ 792.00$ & $\$ 7,920.00$ & $\$ 660.00$ & $\$ 8,400.00$ & $\$ 19,092.00$ \\
\hline Containers & $\$ 2,900.00$ & $\$ 1,740.00$ & $\$ 2,900.00$ & $\$ 600.00$ & $\$ 1,350.00$ & $\$ 9,490.00$ \\
\hline Growing medium & $\$ 2,750.00$ & $\$ 1,650.00$ & $\$ 2,750.00$ & $\$ 500.00$ & $\$ 1,500.00$ & $\$ 9,150.00$ \\
\hline Fertilizer and chemicals & $\$ 155.00$ & $\$ 90.00$ & $\$ 235.00$ & $\$ 200.00$ & $\$ 450.00$ & $\$ 1,130.00$ \\
\hline Tags & $\$ 823.50$ & $\$ 494.10$ & $\$ 823.50$ & $\$ 1,647.00$ & $\$ 0.00$ & $\$ 3,788.10$ \\
\hline Other direct costs & $\$ 0.00$ & $\$ 0.00$ & $\$ 0.00$ & $\$ 0.00$ & $\$ 0.00$ & $\$ 0.00$ \\
\hline Number of units started & 5,000 & 3,000 & 5,000 & 10,000 & 15,000 & 38,000 \\
\hline Square feet per unit & 1.64 & 1.64 & 1.64 & 0.11 & 1.00 & \\
\hline Weeks to grow & 8 & 6 & 13 & 6 & 15 & \\
\hline Percent sold & 0.98 & 0.98 & 0.98 & 0.95 & 0.95 & \\
\hline Sales price & $\$ 6.50$ & $\$ 6.50$ & $\$ 10.00$ & $\$ 1.20$ & $\$ 5.00$ & --- \\
\hline
\end{tabular}


reduce costs or to reduce or eliminate production of poinsettias. Finally, they might increase the price of poinsettias to make them profitable.

4) The results give a breakdown of variable costs per unit.

5) In the example, poinsettias are not profitable, and action should be taken to either eliminate them or make them profitable. Poinsettias have a high overhead cost, alerting management to find ways of reducing it. Possible options include buying prefinished or finished plants, substituting poinsettias with a more profitable crop, or growing more crops throughout the year so that overhead costs for poinsettias are lowered. A major portion of the costs are the rooted cuttings. Another option may be to grow stock plants and produce unrooted cuttings rather than purchasing them.

6) Finally, the program gives information on pricing plants. Because ofthe current cost structure, the price of poinsettias needs to be raised if they are to be profitable. However, increasing the price is usually difficult, because often it is determined by the market. The manager may wish to consider ways of differentiating the product so that the price can be increased.

As shown in this hypothetical example, knowledge of the profitability of each crop helps managers make production and marketing decisions to improve their businesses.

\section{Systems requirements}

The Greenhouse Cost Accounting program assumes that the grower has a grasp of financial management and maintains good records. It comes with a manual and is menu-driven with submenus to guide the user through the program. On-screen instructions are also available.

Two versions of the program are available for DOS-

Table 3. An example from the Greenhouse Cost Accounting program of overhead results when information on specific crop costs is available.

\begin{tabular}{|c|c|c|c|}
\hline \multicolumn{4}{|c|}{$\begin{array}{l}\text { Results section } \\
\text { Overhead and variable costs }\end{array}$} \\
\hline Item & $\begin{array}{l}\text { Values from } \\
\text { income } \\
\text { statement }\end{array}$ & $\begin{array}{l}\text { Values from } \\
\text { cost sheet }\end{array}$ & $\begin{array}{c}\text { Unallocated } \\
\text { costs }\end{array}$ \\
\hline Sales & & $\$ 182,610.00$ & \\
\hline \multicolumn{4}{|l|}{ Direct costs } \\
\hline Seeds, cuttings, or plants & $\$ 19,092.00$ & $\$ 19,092.00$ & $\$ 0.00$ \\
\hline Pots or containers & $\$ 9,490.00$ & $\$ 9,490.00$ & $\$ 0.00$ \\
\hline Growing medium & $\$ 9,150.00$ & $\$ 9,150.00$ & $\$ 0.00$ \\
\hline Fertilizer and chemicals & $\$ 1,130.00$ & $\$ 1,130.00$ & $\$ 0.00$ \\
\hline Tags & $\$ 3,788.10$ & $\$ 3,788.10$ & $\$ 0.00$ \\
\hline Other & $\$ 0.00$ & $\$ 0.00$ & $\$ 0.00$ \\
\hline \multicolumn{4}{|l|}{ Overhead salaries } \\
\hline (including benefits) & $\$ 37,384.00$ & & $\$ 37,384.00$ \\
\hline \multicolumn{4}{|l|}{ General wages } \\
\hline (including benefits) & $\$ 12,111.00$ & $\$ 12,111.00$ & $\$ 0.00$ \\
\hline \multicolumn{4}{|l|}{ Utilities } \\
\hline Heating fuel & $\$ 20,000.00$ & & $\$ 20,000.00$ \\
\hline Electricity & $\$ 3,350.00$ & & $\$ 3,350.00$ \\
\hline Telephone & $\$ 1,480.00$ & & $\$ 1,480.00$ \\
\hline Water & $\$ 0.00$ & & $\$ 0.00$ \\
\hline \multicolumn{4}{|l|}{ Overhead } \\
\hline Depreciation & $\$ 16,750.00$ & & $\$ 16,750.00$ \\
\hline Interest & $\$ 16,800.00$ & & $\$ 16,800.00$ \\
\hline Repairs & $\$ 3,725.00$ & & $\$ 3,725.00$ \\
\hline Taxes & $\$ 550.00$ & & $\$ 550.00$ \\
\hline Insurance & $\$ 3,240.00$ & & $\$ 3,240.00$ \\
\hline Advertising & $\$ 485.00$ & & $\$ 485.00$ \\
\hline Dues and subscriptions & $\$ 100.00$ & & $\$ 100.00$ \\
\hline Travel and entertainment & $\$ 345.00$ & & $\$ 345.00$ \\
\hline Office expense & $\$ 314.00$ & & $\$ 314.00$ \\
\hline Professional fees & $\$ 550.00$ & & $\$ 550.00$ \\
\hline \multicolumn{4}{|l|}{ Truck expense and } \\
\hline equipment rental & $\$ 7,150.00$ & & $\$ 7,150.00$ \\
\hline Land rental & $\$ 2,000.00$ & & $\$ 2,000.00$ \\
\hline Contributions & $\$ 18.00$ & & $\$ 18.00$ \\
\hline Bad debts & $\$ 925.00$ & & $\$ 925.00$ \\
\hline Miscellaneous & $\$ 550.00$ & & $\$ 550.00$ \\
\hline Total unallocated costs & & & $\$ 115,716.00$ \\
\hline
\end{tabular}


Table 4. An example from the Greenhouse Cost Accounting program of output information per unit and per crop.

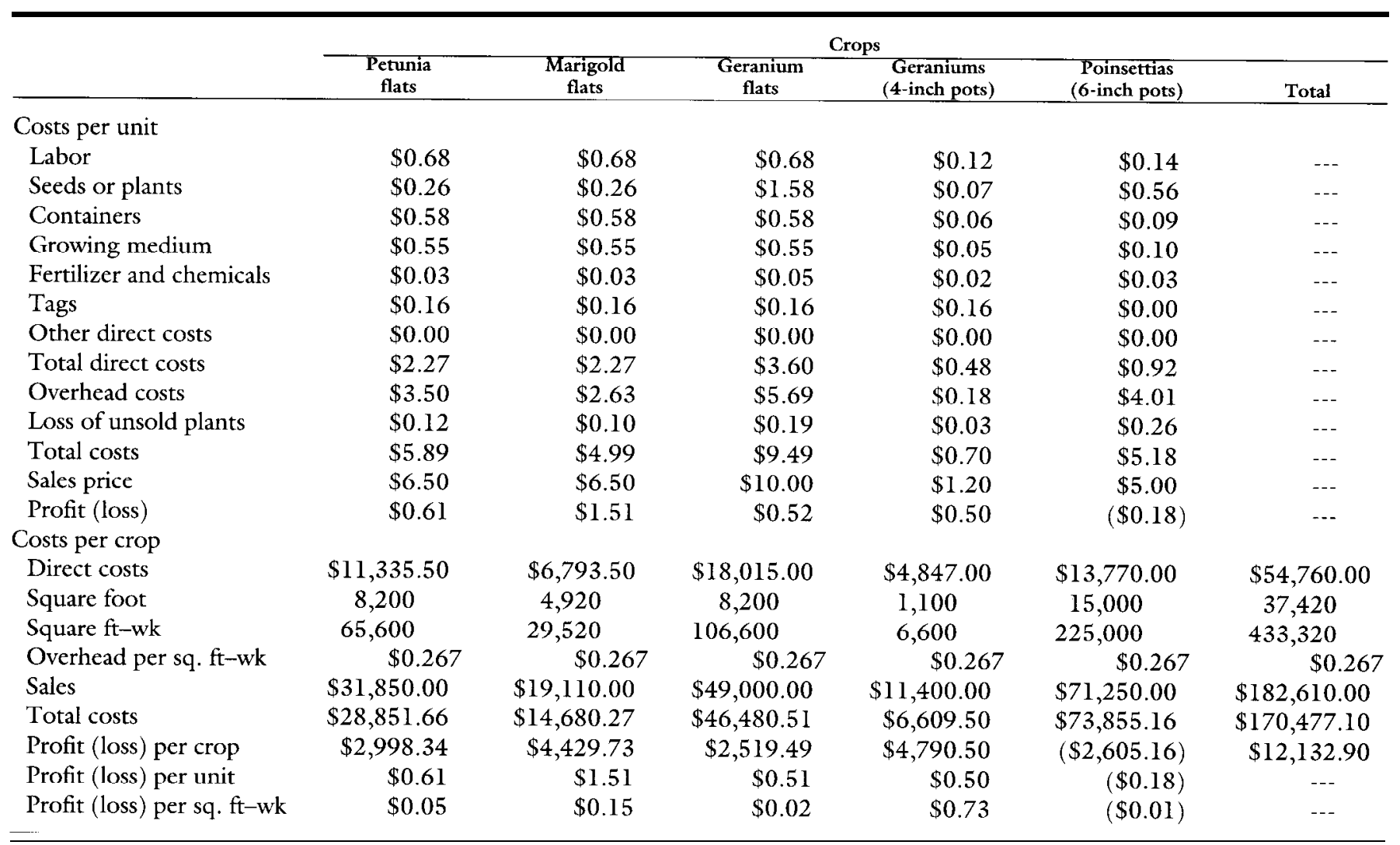

based microcomputers. The Lotus 1-2-3 version requires the user to have Lotus 1-2-3 (version 2.0 or higher) installed on a microcomputer. The compiled version is a stand-alone program that requires no additional software, but it does require a hard-disk drive or 3.5.inch floppy disk drive and $407 \mathrm{~K}$ of hard-disk space. For more information, contact R.G.B., phone 908/932-9171. For a copy of the software, send a $\$ 20$ check (cost ofduplication, postage, and handling), payable to Rutgers-The State Univ., to Gary Huntzinger, Rutgers Cooperative Extension, Office of computer Services, Blake Hall, New Brunswick, NJ 08903-0231; phone 908/ 932-9279. Specify either the Lotus $1-2-3$ or the compiled version on a 5.25 - or 3.5-inch disk.

A program for Macintosh computers is also available that uses Microsoft Excel (version 2.2). For a copy of the Macintosh version, send a \$3 check, payable to The Pennsylvania State Univ., to Attn: Vonnie Henninger, Computer Services, 405 Ag Administration Building, The Pennsylvania State Univ., University Park, PA 16802. Ask for the Greenhouse Cost Accounting program AHO-0802.

\section{Literature Cited}

Crassweller, R.M., P.H. Heinemann, and E.G. Rajotte. 1989. An expert system on a microcomputer for determining apple tree spacing. HortScience 24: 148.
Creasy, L.L. 1986. Application of an apple production and profitability microcomputer model in pomology teaching. HortScience 21:1176-1177.

Embree, C.G., B. W. MacLean, and R.J. O'Regan. 1991. HARVMARK: An interactive computer model for apple harvesting and marketing strategies. HortScience 26: 1560.

Hall, F.R., J.R. Lemon, and D.C. Fererree. 1989. On-farm support system for orchard planning. Acta Hort. 243:399-401.

Power, K.C., J.B. Fitzgerald, G.E. Meyer, and D.D. Schulte. 1991. Plant production cost-accounting/management system. HortScience 26:201-203.

Rhodus, W.T., T.L. Prince, and R.D. Taylor. 1987. An interactive greenhouse profitability model developed for micro-computers. Acta Hort. 203:33-38.

Smith, R.D. and L.A. Arminio. 1986. Project costing with microcomputers. HortScience 21:322-323.

Tripepi, R.R. and F.J. Kuchar. 1988. Plant cost accounting: A microcomputer program to calculate crop production costs. HortScience 23:905-906.

\section{Acknowledgements}

I thank George Wulster, Dept. of Horticulture, Rutgers Univ., for compiling the program. 